\title{
DETERMINATION OF THE OPTIMAL STERILIZATION REGIME OF CANNED QUAIL MEAT WITH HYDROCOLOIDS APPLICATION
}

\author{
Vasil Pasichnyi \\ Department of meat and meat products technology \\ National University of Food Technology \\ 68 Volodymyrska str., Kyiv, Ukraine, 01601 \\ pasww1@ukr.net \\ Anatoliy Ukrainets \\ Laboratory of problematic scientific research \\ National University of Food Technology \\ 68 Volodymyrska str., Kyiv, Ukraine, 01601 \\ info@nuft.edu.ua \\ Dmytro Shvedyuk \\ Laboratory of problematic scientific research \\ National University of Food Technology \\ 68 Volodymyrska str., Kyiv, Ukraine, 01601 \\ shvedyuk.d@ukr.net \\ Al-Hashimi Haider Muhamed \\ Department of meat and meat products technology \\ National University of Food Technology \\ 68 Volodymyrska str., Kyiv, Ukraine, 01601 \\ alhashimi3030@gmail.com

\section{Matsuk Yuliia} \\ Department of Food industry technologies and restaurant industry \\ Poltava University of Economy and trade \\ 3 Kovalay str., Poltava, Ukraine, 36014
}

\begin{abstract}
The use of hydrocolloids in the modern meat industry is the one of prospective directions for improving functional and technological characteristics of meat and meat products, including poultry at long storage terms. A series of concrete requirements to functional-technological, physical-chemical and organoleptic parameters is offered for canned poultry in correspondence with minimal specifications for the quality of products of an animal origin.

There is presented the study of the optimization of the process of meat products sterilization using meat of chicken-broilers, quails and hydrocolloids depending on physical-chemical and organoleptic properties. The parameters of quail meat use in recipes of canned poultry meat with hydrocolloids were considered. The influence of the sterilization process on characteristics of chicken-broiler and quail meat was established.

There was revealed the essential difference in the influence on functional and technological parameters of canned quail meat using hydrocolloid mixtures comparing with canned chicken-broiler meat, manifested in changes of MKC (moisture keeping capacity), plasticity and salt content in jelly. At changing sterilization regimes, there takes place the change of physical and chemical characteristics of gels that correlates with organoleptic characteristics. For providing high quality parameters of canned poultry meat and industrial sterility, sterilization regimes for canned chicken-broiler meat must be realized for containers with the volume 500 with sterilization time no more than 90 minutes. For canned quail meat the sterilization process duration must be increased to $120 \mathrm{~min}$ at the temperature $115^{\circ} \mathrm{C}$.
\end{abstract}

Keywords: poultry meat, sterilization formula, hydrocolloids, quail meat, chicken-broiler meat. Al-Hashimi Haider Muhamed, Matsuk Yuliia 


\section{Introduction}

Under modern conditions the use of hydrocolloids in the meat industry is the one of prospective directions of raising functional-technological parameters of meat and meat-containing products, including ones of poultry of long storage terms. A series of concrete requirements to functional-technological, physical-chemical and organoleptic parameters is offered for canned poultry in correspondence with minimal specifications for the quality of products of an animal origin, such as a mass share of salt and jelly in a product, specific smell and taste. The most important requirement is a correspondence to microbiological safety norms. Alongside with high organoleptic and physical-chemical parameters of canned poultry, the important problem is to provide the complete sterility of these types of canned food that determines the microbiological safety for a consumer [1-3].

The search for optimal sterilization regimes and selection of canned meat recipes is provided by the use of new types of a raw material, food additives and elaboration of the sterilization formula for new types of canned meat.

A sterilization regime for canned poultry meat must provide the microbiological safety of a product and preserve maximally high organoleptic parameters. From this point of view it is especially urgent to elaborate the sterilization formula for new types of canned poultry meat.

At using poultry meat in recipes of canned meat this raw material is used with bones, expect tubular ones for several species of poultry. The use of too much soft sterilization regimes for these species of poultry doesn't lead to softening of bones that may be dangerous for a consumer at taking poultry meat to pieces because of their acute ends [4]. At more long sterilization with higher temperature values, organoleptic characteristics of canned food decrease alongside with the great energy consumption of the process. Meat loses its color, taste, its structure becomes too much crumbly, jelly share increases that is not wanted.

To improve the product consistence and to increase the jelly capacity in canned meat, it is prospective to use hydrocolloids [5-7]. The use of hydrolocolloids increases organoleptic parameters and density of a product in a container and decreases diffusion of nutritive substances that may transform from the meat raw material into jelly.

\section{Materials and Methods}

To organize the technological process of canned food production there was used the technological instruction with TC U 15.1-02070938-054: 2005 "Canned meat with food compositions", elaborated in the National University of food technologies (Ukraine).

The technology of canned food production included the raw material preparation (cleaning, washing and cutting of carrot), pickle preparation (hydration of food compositional mixtures NASHA KS and NASHA SB (NASHA PP, Ukraine) with salt addition), cleaning and washing of quail trunks and wings of chicken-broilers. After that recipe components were dosed in preliminary washed glass containers, containers were corked, washed. The sterilization was realized in the laboratory autoclave VK-30 (Russia) corresponding to the sterilization plan, then hot and cold sorting of sterilized canned food and taking of samples for further studies were realized.

Canned foods were kept in the thermostat at $37{ }^{\circ} \mathrm{C}$ during 5 days [8]. At keeping in the thermostat, they were examined every day. After the thermostatic keeping and cooling of canned foods during 24, container defects were not revealed.

After thermostatic keeping selected samples of canned food were opened and a sample was taken after averaging of the netto content. A mean sample contained liquid and hard phase of canned foods. The sample was used to reveal viable cryptogamic forms of bacteria. For that $1 \mathrm{~g}$ of the averaged sample of the sterilized product was added in 2 tubes with thioglycolic medium and in 2 tubes with Kitt-Tarozzi medium, incubated at the temperature $30{ }^{\circ} \mathrm{C}$ during 5 days [8].

To reveal molds and yeast $1 \mathrm{~g}$ of the canned food was added in 2 tubes with bouillon. The inoculations were incubated at the temperature $24{ }^{\circ} \mathrm{C}$ during 5 days [8].

To reveal fermented milk microorganisms, $1 \mathrm{~g}$ of the mean sample of the canned food was added synchronously in 2 tubes with Blickfeldt medium. The inoculations were incubated at the temperature $30{ }^{\circ} \mathrm{C}$ during 5 days [9]. "Canned food. Method of industrial sterility determination" [8]. 
At incubation the everyday observation of signs of microorganisms' appearance was realized.

MKC determination in the meat part of canned food was realized by the pressing method [9]. It included a batch taking $(0,3 \mathrm{~g})$ using torsion scales, it pressing by a load with the mass $1 \mathrm{~kg}$ on the filtering paper, determination of the area of a wet spot and forcemeat spot. The calculation of MKC (moisture keeping capacity) (\%) was realized by the formula

$$
\mathrm{MKC}=\frac{100(\mathrm{a}-8,4 \cdot \mathrm{S})}{\mathrm{a}}
$$

where a - mass of moisture in the product batch, $\mathrm{mg} ; \mathrm{S}$ - area of moisture spot, $\mathrm{cm}^{2}$.

Plasticity $\left(\mathrm{cm}^{2} / \mathrm{g}\right)$ was also calculated by measured areas of forcemeat spots, according to the formula

$$
\mathrm{P}=\frac{\mathrm{S}_{\mathrm{f}} \cdot 1000}{\mathrm{~m}}
$$

where $\mathrm{S}_{\mathrm{f}}$ - area of a forcemeat spot, $\mathrm{cm}^{2}, \mathrm{~m}$ - batch mass, $\mathrm{mg}$.

The salt content in meat and jelly was determined by Mohr method in correspondence to the requirements of TC U 15.1-02070938-054: 2005.

The determination of organoleptic parameters was realized on five point evaluation scale by the tasting estimation with the mean result fixation in the protocol. The maximal mark was 5 points. Estimations were realized by the group of 10 persons.

The general experiment on the influence of sterilization conditions on quality parameters of canned food was realized by the plan CFE $2^{2}$, where the influence factors were selected as time and temperature of sterilization. As the main parametric criteria of sterilization process quality were considered: physical-chemical, organoleptic and microbiological parameters of produced canned foods [6].

The recipe "Fragrant chicken meat", according to TC U 15.1-02070938-054:2005 served as a control. Experimental samples included wings of chicken-broilers and quail meat. Recipes of samples are presented in Table 1.

Canned foods sterilization was realized according to the plan, Table 2.

\section{Table 1}

\begin{tabular}{|c|c|c|c|}
\hline \multirow{2}{*}{ Raw material } & \multicolumn{3}{|c|}{ Quantity of raw material, \% } \\
\hline & Control & Sample 1 & Sample 2 \\
\hline Quail meat on a bone & - & - & 65,0 \\
\hline Chicken-broiler meat & 65,0 & 65,0 & - \\
\hline Kitchen salt, no lower than 1 sort & 1,69 & 1,69 & 1,69 \\
\hline $\begin{array}{l}\text { White roots or carrot, raw or marinated } \\
\text { (both variants are possible) }\end{array}$ & 3,87 & 3,87 & 3,87 \\
\hline NASHA KS No. 393 & 0,43 & - & 0,43 \\
\hline NASHA SB No. 269 & 1,24 & - & 1,24 \\
\hline Water for hydration & 27,77 & 29,44 & 27,77 \\
\hline Bay leaf, un for 1 container & 1 & 1 & 1 \\
\hline
\end{tabular}

Variants of recipes of experimental samples of canned foods 
Table 2

Regimes of canned foods sterilization according to the plan CFE $2^{2}$

\begin{tabular}{ccccc}
\hline $\begin{array}{c}\text { No. in } \\
\text { order }\end{array}$ & $\begin{array}{c}\text { Sterilization } \\
\text { temperature, }{ }^{\circ} \mathbf{C}\end{array}$ & $\begin{array}{c}\text { Sterilization } \\
\text { time, } \text { min. }\end{array}$ & $\begin{array}{c}\text { Heating time to steriliza- } \\
\text { tion temperature, min. }\end{array}$ & $\begin{array}{c}\text { Cooling time after } \\
\text { sterilization, min. }\end{array}$ \\
\hline 1 & 115 & 90 & 20 & 20 \\
2 & 120 & 90 & 20 & 20 \\
3 & 115 & 120 & 20 & 20 \\
4 & 120 & 120 & 20 & 20
\end{tabular}

\section{1. Experimental procedures}

For studying rheological characteristics of jelly (gels) of canned foods, samples were taken after the thermal processing of canned foods with poultry meat, sterilized corresponding to TC U 15.1-02070938-061: 2005 for this container volume (500 ml) $(20$ minutes of heating, 90 minutes of sterilization to the temperature $115^{\circ} \mathrm{C}, 20$ minutes of cooling to the temperature of autoclave depressurization $50^{\circ} \mathrm{C}$ ).

Samples of sterilized gels were studied on the rotary viscosimeter "Reotest-2" (Germany) using the standard set of cylinders at the temperature $18-20{ }^{\circ} \mathrm{C}$ according to the method of the work with the equipment [10]).

After taking readings, values of effective viscosity and tangential shift tension were calculated corresponding to constant coefficients for applied cylinders and ones of rotating speed were calculated corresponding to the certificate of "Reotest-2" [10].

\section{Results}

The estimation of organoleptic parameters by regime 1 (Table 2) demonstrated high organoleptic parameters in the control sample. Meat in the control sample can be easily separated from jelly, its consistence is rather soft and juicy, meat and jelly have a pleasant taste and color. Jelly in the control sample has the high density. Sample 1 (Table 1) of canned foods has a bit worse parameters comparing with the control. Jelly in sample 1 has less dense consistence, meat - denser than in the control. The taste and smell of the product were less expressed than in the control. Organoleptic parameters in sample 2 (Table 1) (quail canned meat) were essentially inferior to the control. Meat was insufficiently boiled, dense, with hard small bones that may be dangerous for a consumer.

According to microbiological parameters, all samples corresponded to norms of the industrial sterility, presented in Table 3.

Table 3

Parameters of the industrial sterility of canned foods

\begin{tabular}{cc}
\hline $\begin{array}{c}\text { Spore-constituent microorganisms of } \\
\text { Bacillus group }\end{array}$ & $\begin{array}{c}\text { Mesophyll clostridia except } \\
\text { Cl.botulinum, Cl. Perfringens, in 1gr }\end{array}$ \\
\hline Not allowed & No more than 1 cell \\
Not revealed (for all samples) & Not revealed (for all samples) \\
SS 30425-97 & SS 30425-97
\end{tabular}

The difference between physical-chemical parameters of canned foods was unessential except MKC (moisture keeping capacity) value.

From the data, presented in Table 3 one can make a conclusion that the regime of 1 sterilization formula $\left(20-90-20 / 115^{\circ} \mathrm{C}\right)$ is enough to provide the industrial sterility of canned foods with the container volume $500 \mathrm{ml}$. But this sterilization regime is inappropriate for manufacturing canned foods with quail meat. The enough effect of meat and small bones boiling is not attained in the sample.

The sterilization according to regimes, 3 and 4 (Table 2) was realized only for canned foods of quail meat by recipe 2 (Table 1), because regime 1 provided the enough sterility and organoleptic parameters for chicken-broilers meat but was not enough for quail meat. 
At the sterilization at the temperature $120^{\circ} \mathrm{C}$ during 90 minutes (regime 2, Table 2) the essential improvement of organoleptic and physical-chemical parameters was observed, but the insufficient level quail small bones boiling remained.

Physical-chemical parameters of canned foods essentially decreased that was especially evident on the example of MKC value $(63,5 \%$ against $76,15 \%$ by the first sterilization variant). The received results allow to make a conclusion about the inconsistency of sterilization regime to declared requirements.

Parameters of canned foods by the third sterilization regime (Table 2) demonstrated high organoleptic and physical-chemical parameters of canned foods with quail meat. The salt content is within norm and did not undergo visible changes, product plasticity increased and its consistence became visibly tender, small bones could be chewed. MKC of product meat was a bit more than an analogous value, received in the previous series of experiments. We can make a conclusion that this sterilization formula provides the declared parameters.

The fourth sterilization regime (Table 2) with the maximal thermal exposition gave canned foods with the excessive meat plasticity and low organoleptic parameters of meat and jelly. Jelly contained clots that did not melt and crfated the heterogenous structure.

\section{Conclusions}

To provide the high quality parameters of canned foods with poultry meat and to attain the industrial sterility, sterilization regimes for canned foods of chicken-broiler meat must be realized for a container with the volume $500 \mathrm{ml}$, with the sterilization time no more than 90 minutes. For canned foods of quail meat the sterilization process duration must be increased to 120 minutes at the temperature $115^{\circ} \mathrm{C}$.

The strength on this study is the practical establishment of differences in the process of sterilization of canned foods of different types of poultry meat using hydrocolloids. The shortcoming of the study is the narrow spectrum of applied results. To receive more generalized regularities the author group plans to investigate the process of sterilization of canned foods of quail meat using hydrocolloids for other types of a container for canned foods. The received results may be used at the elaboration of new recipes of canned foods using quail meat.

\section{References}

[1] Silva, F. V. M., Gibbs, P. A. (2012). Thermal pasteurization requirements for the inactivation of Salmonella in foods. Food Research International, 45 (2), 695-699. doi: 10.1016/j.foodres.2011.06.018

[2] Fadi, A., Mohammad, J. (2012). Effect of Temperature preservation on Bacterial Survival of Poultry Meat. Available at: http://repository.sustech.edu/handle/123456789/1654

[3] Lee, J. J., Kim, D. H., Lim, J. J., Kim, D. G. et. al. (2011). Sterilization effects of avian influenza virus and newcastle disease virus in chicken muscle and organs dependent on autoclaving time. Korean Journal of Veterinary Public Health, 35 (4), 270-274. Available at: http://agris.fao.org/agris-search/search. do?recordID=KR2012004468

[4] Yastreba, Yu. A., Polozhyshnykova, L. A., Pasychniy, V. N. (2015). Tekhnolohyya myasnikh konservov s ispol'zovanyem al'hynata natryya. Naukovyi visnyk L'vivs'koho natsional'noho universytetu veterynarnoyi medytsyny ta biotekhnolohiy imeni S. Z. Gzhyts'koho, 17 (4 (64)).

[5] Pryanyshnykov, V. V. (2010). Innovatsyonnie tekhnolohyi proyzvodstva konservov iz myasa ptytsu. Ptytsa i ptitseproduktu, 5, 21-22.

[6] Pasichnyi, V. M., Sabadash, P. M. (2005). Vykorystannya hidrokoloidiv u vyrobnytstvi konserviv z m’yasom ptytsi. Kharchova promyslovist, 4, 61-63.

[7] Strashynskiy, I., Fursik, O., Pasichniy, V., Marynin, A., Goncharov, G. (2016). Influence of functional food composition on the properties of meat mince systems. Eastern-European Journal of Enterprise Technologies, 6 (11 (84)), 53-58. doi: 10.15587/1729-4061.2016.86957

[8] GOST 30425-97. Konservy. Metod opredeleniya promyshlennoy steril'nosti. Available at: http:// www.internet-law.ru/gosts/gost/9107/

[9] Pasichnyi, V. M., Tymoshenko, I. V. (2014). Optymizatsiya tekhnolohichnykh protsesiv haluzi. Kyiv: NUKhT, 67.

[10] VEB MLW Instrukciya po ekspluatacii REOTEST 2 - cilindricheskiy i konuso-plastinochnyy rotacionnyy viskozimetr (1979). MLW, 50. Available at: http:/www.pochva.com/?content=3\&book_id=1311 